Orr (now Lord Boyd-Orr) could contend in a book review for Nature that "proof of the overwhelming influence of environment is given in evidence showing that, as the standard of living of the poorest class rises, there is a reduction of disease, an increase in the average length of life and an improvement in intelligence"71. Thereafter the journal moved closer and closer to Boyd-Orx's viewpoint ${ }^{72}$, until it reached a completely agnostic position on the relationship between social class and intelligence ${ }^{73}$.

Gregory's doubts about eugenics were paralleled by second thoughts on the wisdom of planning in general. As the racial doctrine of the Fascists occasioned one shift in policy, so also did their version of "rationalization" prompt another. Sir Richard began to sense in the mid- thirties that restrictions of personal liberty were inseparable from any form of planning. Under the aegis of a dictator (or even a scientific élite) the encroachments upon freedom and science might become intolerable. Brightman's outlook apparently had evolved in a similar manner, since in June of 1938 he granted that "the internal success of the totalitarian States has already ... provoked serious doubts as to how much can be hoped for from planning even in a Democratic State"74. Here was a considerable dilemma. Science, "emancipated from authority", had created a need for rationalization, which in turn demanded a central decision-making body for its successful operation ${ }^{74}$. If the experiences of scientists under Hitler were at all typical, then science might contain

\title{
A REMARKABLE PAINTED CAVE ON THE ESTATE OF LESCAUX (MONTIGNAC, DORDOGNE)
}

\author{
By Prof. the Abbé Henri Breuil
}

\section{Collège de France}

$\mathrm{I}^{\mathrm{N}}$ $\mathbf{N}$ mid-September 1940, several young lads of Montignac, MM. Ravitat, Marsal, Quéroy, Cuëncas, and Estrégil, encouraged by a retired schoolmaster of the town, M. Laval, to explore underground passages in the neighbourhoor, cleared out a shaft leading vertically from a plateau to the east of the town. This shaft had been filled up to prevent cattle falling in and only a narrow passage led to the bottom, ending in a hollow into which the young explorers slid after having enlarged it. Descending a slope of fallen boulders, they discovered that some of those fallen from the vault of the first hall were decorated with magnificent frescoes which continued down a narrow alley leading out of it. M. Estrégil made several sketches of these, which he showed to M. Laval, who was at first sceptical about them. Whereupon M. Maurice Thaon, a good sportsman and draughtsman, whom I had known since his childhood, and to whom, a few days earlier, I had shown the painted caves of Font-de-Gaume and La Mouthe, at Les Eyzies, was taken to the cave by the youthful discoverers, and brought careful drawings and some tracings to me.

His descriptions convinced me of the exceptional importance of the discovery. I therefore went to Montignac, where M. Laval, M. Parvan, bailiff of the proprietor, Madame la Comtesse Emm. de la Rochefoucault, and various distinguished people received me most kindly. I asked $M$. D. Peyrony, delegate of the Ministry of Fine Arts, to meet me there, and a three days' study enabled me to send a preliminary report to the Académie.

The cave in its present state consists of an oval entrance hall $(20 \mathrm{~m} . \times 10 \mathrm{~m}$.$) continuing in a$ narrow passage. In the second half of the hall and in the passage there are more than eighty paintings, chiefly on blocks fallen from the vault above. In a short gallery to the right, there are fewer; but this gallery leads to another lofty hall -sloping siseply and leading on the left to a corridor with a high nave, shrinking to a slit of a passage, extremely narrow in parts.

Beyond the lofty hall is a well about $10 \mathrm{~m}$. deep leading by a scramble on the opposite side to ascending galleries, as yet almost unexplored. In the high nave, engravings are generally superposed on paintings ; but ther are unaccompanied in the tortuous galleries; their great number and delicacy have prevented us from deriphering them adequately, as yet.

There are neither reindeer nor mammoth, and besides the animal figures there are a good many signs; rectangles barred length wise and across; five-pronged comb-shaped signs, chessboard patterns filled with big squares of flat wash, the colours arranged in varied ways, looking like coats of arms: lances or javelins with a single barb; arrows, feathered on one side.

The foot of the well boasts a more unusual subject; to the left a black rhinoceros walks slowly away; in the centre, drawn in red, a half. eonventionalized man is lying beside a javelin and a throwing stick. To the right, a sand-coloured bison outlined in black gazes at him; its entrails seem to be flowing out like a horse ripped open in a bull-fight. It looks like a scene in a prehistoric drama. Near the man a bird is perched on a post. 